DOI: https://doi.org/10.47405/mjssh.v6i11.1149

\begin{tabular}{|c|c|}
\hline & Malaysian Journal of Social Sciences and Humanities (MJSSH) \\
\hline Malaysian Journal of & Volume 6, Issue 11, November 2021 \\
\hline (Mulssh) & e-ISSN : 2504-8562 \\
\hline & $\begin{array}{l}\text { Journal home page: } \\
\text { www.msocialsciences.com }\end{array}$ \\
\hline
\end{tabular}

\title{
User Satisfaction of the Free Shuttle Bus Service in Petaling Jaya
}

\author{
Nur Adibah Farhanah Binti Ismail ${ }^{1}$, Nur Alya Imani Binti Ismail ${ }^{1}$, Nur Intan Faaiqah Binti Mohd \\ Faizal $^{1}$, Nur Rabiatul Adawiyah Atiqah Binti Ijaman', Nuramira Adiyana Binti Suzeli', \\ Nurul Ainina Binti Amir Ezam1, Tan Sheau Wei1, Vimala Davy G. Ramiah², Sio Ching Hee³, \\ Isai Amutan Krishnan4 \\ 1University of Malaya Centre for Continuing Education (UMCCeD), Malaysia \\ ${ }^{2}$ Institute Aminuddin Baki, Sarawak Branch, Kuching, Sarawak, Malaysia \\ ${ }^{3}$ ELM Business School, HELP University, \\ Jalan Sri Semantan 1, Off Jalan Semantan, Bukit Damansara, 50490 Kuala Lumpur, Malaysia \\ ${ }^{4}$ School of Liberal Arts, Science and Technology, PERDANA University, Suite 5.3 5th Floor Wisma Chase Perdana Jalan \\ Semantan Damansara Heights, Wilayah Perseketuan, Malaysia \\ Correspondence: Isai Amutan Krishnan (amuthanisai@gmail.com)
}

\begin{abstract}
Public transportation brings more convenience to customer in urban and rural areas. In Malaysia, awareness of using the PJ City bus by passengers in Petaling Jaya is still limited. Many passengers are still unsatisfied with the services provided because the shuttle bus is zero-priced services, so the quality of services are always questioned by access users. Therefore, this current study is to investigate the influences of value, quality and reputation of free shuttle (PJ City) bus services towards customer satisfaction. Understanding what customers expect is very important as it will help to improve the services. Data were collected from users of PJ City bus using a survey questionnaire. The finding further revealed that, value positively influenced the satisfaction of customers. So, it is important for the service provider to enhance its value to the customer.
\end{abstract}

Keywords: user satisfaction, value, quality, reputation, free shuttle bus, Petaling Jaya

\section{Introduction}

The increasingly active use of cars in and around the cities in industrialized countries has led to the increased accessibility problems as reflected in traffic, $\mathrm{CO} 2$ pollution, global warming, and noise. In order to prevent these problems, many researchers as well as public decision makers have attempted to provide an attractive public transport service such as busses as an alternative transport mode in many cities. Bus services should become part of a solution for sustainable transport in the future. Thus, in order to keep and attract more passengers, bus services must have high service quality, value, reputation and fulfil a more wider range of different need and also customer's satisfactions. PJ City Bus is a free bus services initiated by the City Council of Petaling Jaya (MBPJ) meant to reduce traffic jams and other problems in Petaling Jaya. There are 22 buses including two electric buses that operate the four routes which are PJ01, PJ02, PJ03 and PJ04. The operating hours are from 6 a.m. to 9 p.m.

In Malaysia, awareness of using the PJ City free shuttle bus by passengers in Petaling Jaya is still limited. On the other hand, many passengers are satisfied with the free shuttle bus services provided in Petaling Jaya, but others are still not satisfied with the services provided. It is because, as the shuttle 
bus is zero-priced services, the quality of services always are questioned by access users. The customers concern are whether their demands or expectation can be fulfilled by the zero-priced services. (Parahoo et al., 2014). The objectives of this research are to study the influences of value, quality, and reputation of the free shuttle (PJ City) bus services provided are up to the customer satisfaction in Petaling Jaya.

\section{Literature Review}

Many theories have been proposed to explain what leads to customer satisfaction on the free shuttle bus in Petaling Jaya which called PJ City Bus. Based on the studies of Parahoo et,91; (2014), three elements have been used for the paper. This literature review, discusses the satisfaction of passengers based on three elements which are quality, value and reputation on free shuttle Bus services. The definition is explained according to the past studies that had been done by scholar. Although this paper has three elements that are presented but the main focus is the quality. However, most of the results from previous studies on public transportation have shown that value influences customers satisfaction.

\section{Definitions}

\section{Customer Satisfaction}

According to the Haji Hamzah, Ayub and Hilmi (2015) who stated that in order to keep pace in business, customer satisfaction is a central focus. Hence, Philip Kotler (2017) defines customer satisfaction as feelings of a 'person pleasure by comparing a product or services performance with his or her expectations.' Njei (2018) says that for business, customer satisfaction is the key to success.

Table 1: Definition of customer satisfaction

\begin{tabular}{lll}
\hline NO & AUTHOR NAMES & DEFINITION \\
\hline 1. & $\begin{array}{l}\text { Haji Hamzah, Ayub \& Hilmi } \\
(2015)\end{array}$ & $\begin{array}{l}\text { To keep pace in business, customer satisfaction will be a } \\
\text { central focus. }\end{array}$ \\
2. & Kotler (2017) & $\begin{array}{l}\text { Defines customer satisfaction as feeling of a 'person } \\
\text { pleasure by comparing a product or services performance } \\
\text { with his or her expectations.' }\end{array}$ \\
3. & Njei (2018) & For business, customer satisfaction is the key to success. \\
\hline
\end{tabular}

\section{Quality}

In general, quality is a standard measurement of services or product. Imam (2015) stated that quality of services can maintain existing users and attract new passengers. Yet, Ababneh (2017) define that service quality is not evaluated solely as one time experience but as continuous service access.

Table 2: Definition of quality

\begin{tabular}{lll}
\hline NO & AUTHOR NAMES & DEFINITION \\
\hline 1. & Imam (2015) & $\begin{array}{l}\text { Quality of services can maintain existing users and attract } \\
\text { new passengers. }\end{array}$
\end{tabular}

2. Ababneh (2017)

Service quality is not evaluated solely as a one time experience but as continuous service access. 


\section{Value}

According to Sumedi, Bakti, Rakhmawati, Astrini, Widianti and Yarmen (2016) who define value as an important factor can influence passenger satisfaction. Based on Marbach, Lages and Nunan (2016) who have stated that it is a term that is important in marketing activities.

Table 3: Definition of value

\begin{tabular}{lll}
\hline NO & AUTHOR NAMES & DEFINITION \\
\hline 1. & Sumaedi, Bakti, Rakhmawati, Astrini, & Value is an important factor that can influence \\
& Widianti \& Yarmen (2016) & passenger satisfaction. \\
2 & Marbach, Lages \& Nunan (2016) & $\begin{array}{l}\text { Value is a term which is imperative for every type of } \\
\text { marketing activity. }\end{array}$ \\
\hline
\end{tabular}

\section{Reputation}

Reputation is an opinion towards an entity based on its particular characteristics. Qomariah (2017) has stated that brand image can give an impact to customer satisfaction but does not affect customer loyalty

Table 4: Definition of Reputation

\begin{tabular}{lll}
\hline NO & AUTHOR NAMES & DEFINITION \\
\hline 1. & Qomariah (2017) & $\begin{array}{l}\text { Brand image can give an impact to customer satisfaction but } \\
\text { does not affect customer loyalty. }\end{array}$ \\
\hline
\end{tabular}

\section{Past Studies}

Table 5: Past studies

\begin{tabular}{|c|c|c|c|}
\hline Article/ Title & Objective & $\begin{array}{l}\text { Significance of the } \\
\text { Study }\end{array}$ & Finding \\
\hline $\begin{array}{l}\text { 1) Services quality and } \\
\text { customer satisfaction: } \\
\text { Rapid Kuantan in } \\
\text { Kuantan Route, } \\
\text { Malaysia. (Liu, Siali, } \\
\text { Darun \& Ismail, 2014) }\end{array}$ & $\begin{array}{l}\text { To evaluate customer } \\
\text { satisfaction towards the } \\
\text { quality of service } \\
\text { provided by Rapid } \\
\text { Kuantan from the } \\
\text { dimensions of } \\
\text { reliability, tangibility, } \\
\text { responsibility, } \\
\text { assurance and empathy. }\end{array}$ & $\begin{array}{l}\text { To give more } \\
\text { convenience towards } \\
\text { customers in urban } \\
\text { and rural areas. }\end{array}$ & $\begin{array}{l}\text { Results verify that the } \\
\text { five quality of service } \\
\text { dimensions positively } \\
\text { contribute to customer } \\
\text { satisfaction for Rapid } \\
\text { Kuantan. }\end{array}$ \\
\hline $\begin{array}{l}\text { 2)Measuring } \\
\text { Customer's } \\
\text { Satisfaction on Bus } \\
\text { Transportation (Rabiul } \\
\text { Islam, Mohammed S. } \\
\text { Chowdhurry, } \\
\text { Mohammad Sumann } \\
\text { Sarker \& Salauddin } \\
\text { Ahmed, 2014) }\end{array}$ & $\begin{array}{l}\text { To examine the factors } \\
\text { that measure customers } \\
\text { satisfaction, especially } \\
\text { the impact of quality of } \\
\text { service on customers' } \\
\text { satisfaction in public } \\
\text { transportation. }\end{array}$ & $\begin{array}{l}\text { To give satisfaction } \\
\text { and quality services } \\
\text { to the passengers } \\
\text { using public } \\
\text { transport. }\end{array}$ & $\begin{array}{l}\text { All hypotheses were } \\
\text { tested using Pearson } \\
\text { correlations. Indicated } \\
\text { the hypothesis } 1 \text { through } \\
5 \text { were supported. } \\
\text { Showed that quality } \\
\text { service influenced } \\
\text { overall customer } \\
\text { satisfaction in using } \\
\text { public transport. }\end{array}$ \\
\hline $\begin{array}{l}\text { 3)Determinants of } \\
\text { Customer Satisfaction } \\
\text { of Quality Service : }\end{array}$ & $\begin{array}{l}\text { Ito dentify the } \\
\text { components of } \\
\text { satisfaction of public }\end{array}$ & $\begin{array}{l}\text { Transportation } \\
\text { authorities can use } \\
\text { these findings as a }\end{array}$ & $\begin{array}{l}\text { Succeeded in developing } \\
\text { three dimensions of } \\
\text { public transport that }\end{array}$ \\
\hline
\end{tabular}


City Bus Service in

Kota Kinabalu, Malaysia (Harifah

Mohd Noor, Naasah

Nasrudin \& Jurry Foo, 2014)

4) User Satisfaction of Public Transport: An Exploratory Study in Penang, Malaysia (Halizan Hamzah, Meor Azli Ayub \& Mohd Faiz Hilmi, 2015)

5 )Measuring Public Transport Satisfaction from User Surveys (Imam, 2015)

\section{6)A Study on}

Customer Satisfaction of Public Transport in Melaka by using quality service (Elma Zulaika AB Manaf, 2015)

\section{7) Assessing}

Passengers'

Satisfaction Level on

Bus Services in

Selected Urban and

Rural Centres of

Peninsular Malaysia

(Zakiah Ponrahono,

Syahriah Bachok,

Mansor Ibrahim \&

Mariana Mohamed

Osman, 2016)

DOI: https://doi.org/10.47405/mjssh.v6i11.1149

bus service in Kota

Kinabalu City,

Malaysia. guide to enhance the quality of life of public transport users in the future.
Intended to find the influence of perceived value, quality and reputation of public bus transport on customer satisfaction.

Focuses on the users' satisfaction of the public transportation system in city. A user survey was developed to explore the satisfaction of bus , minibus and jitney users.

To determine customer satisfaction by using the SERVQUAL

dimensions and investigate whether they are satisfied with the service offered by public transport in Melaka.

Main objectives are to evaluate the quality of bus service quality of service through passengers' satisfaction using survey.
To provide good services to enhance its value to the passengers. contributed to satisfaction in the area of study are namely comfort, accessibility and safely. The study found that there is a slight difference in satisfaction between the minibus and bus transit.

Revealed that, value positively influences the satisfaction of customer using public bus services in Penang.
Improvements will make the city more sustainable and reduce the use of private cars in the future.

Opportunities help to manage, to improve business and profit of the company especially to keep loyalty of its customers.

To support the economic growth, the growing population and the expansion of urban or rural transportation activities.
Panorama Melaka has performed good quality services. It was done through the analysis of the dimension in order to measure the relationship between the service by Panorama Melaka and their customer.

Result show sociodemographic and trip characteristics influenced the satisfaction level and passengers' expectation of future bus services improvements. 
8) Public Perception in Public Transportation in Malaysia. (Santuri \& Baharom, 2018) DOI: https://doi.org/10.47405/mjssh.v6i11.1149

Analyse public perception of public transportation in Malaysia.

\section{9)Customer}

Satisfaction on Quality service of Bus

Transport: A Survey

on Passengers from

Phnom Penh to Poipet

in Cambodia

(Sokchan Ok, 2018)
Intended to find out and

how to improve

customer's satisfaction

in private bus

companies.
Public can choose the transportation that want to use in accordance with the needs to support daily activities of the community. All types of transportation have provided comfort for the community, They have become easy and cheap for passengers.

To evaluate the main factors affecting the bus quality of service and customer satisfaction in bus services to travel from Phnom Penh to Poipet which are providing by private companies.

\section{Help to ascertain} whether quality of service meets or exceeds the expectations of the passengers.
Showed that people used various types of public transport in Malaysia according to their daily needs.
For the question of customer's reason to use bus transport, "suitable travelling" ranked last among the factors. Also, more than half of the respondents stated that they may use public transport again in the future, because there is no choice for them.

Revealed that public transport passengers are significantly influenced by quality of service . of service: Public

Transport in Kuala

Lumpur (Hamza

Imhimmed Mohamed

Irtema, Amiruddin

Ismail, Muhamad

Nazri Borhan, Hassan

M Abdelsalam,

Abdurauf.B.Z

Alshewi, Shaban

Ismael Albrka,

Abdalrhman Milad,

Buseif Mohashhash,

Aboubaker Y.Y.

Alfakhri, Amsori

Muhammad Das,

Hussin A.M Yahia \&

Musbah Al Allam, of passengers using

public transport with

respect to the quality of service of public

transport. 2018)

First of all, the articless above are references of this current case study. The article by Halizan Hamzah, Meor Azli Ayub \& Mohd Faiz Hilmi, (2015) has been used as a guide and and source of information for this current case study. All the previous case studies stated above have mentioned about customer satisfaction and the quality of services of the public transport. Besides, the previous case studies that were conducted not only focused on bus but the other forms of public transport as well. 
In the article on the "User Satisfaction of Public Transport: An Exploratory Study in Penang, Malaysia" by Halizan Hamzah, Meor Azli Ayub and Mohd Faiz Hilmi, (2015) there is evidence that reputation, quality, and value influence the satisfaction for the use of public transport services (Parahoo et al., 2014). Their case study focused on public bus transport only and the results of the research are similar to this current case study.

To conclude, the quality of the service affects the customer perceptions and satisfaction. Indeed customers who are satisfied become loyal and fo them to be satisfied, quality of service is important (Lovelock and Wirtz, 2004). It is proven that there is a positive relationship between quality of services and user satisfaction. Therefore, this current case study will focus on quality, value and reputation of the free shuttle bus in Petaling Jaya that depends on user satisfaction.

\section{Methodology}

A survey method was used to collect the data for the study. The target respondents are the free bus transportation users in Petaling Jaya and they are from different levels of the society. According to the Morgan table, three hundred and twenty-two respondents from two thousand and seventy people who use the free bus transportation in Petaling Jaya answered the questionnaires. This survey consisted of two parts.

Figure 1: Conceptual Framework

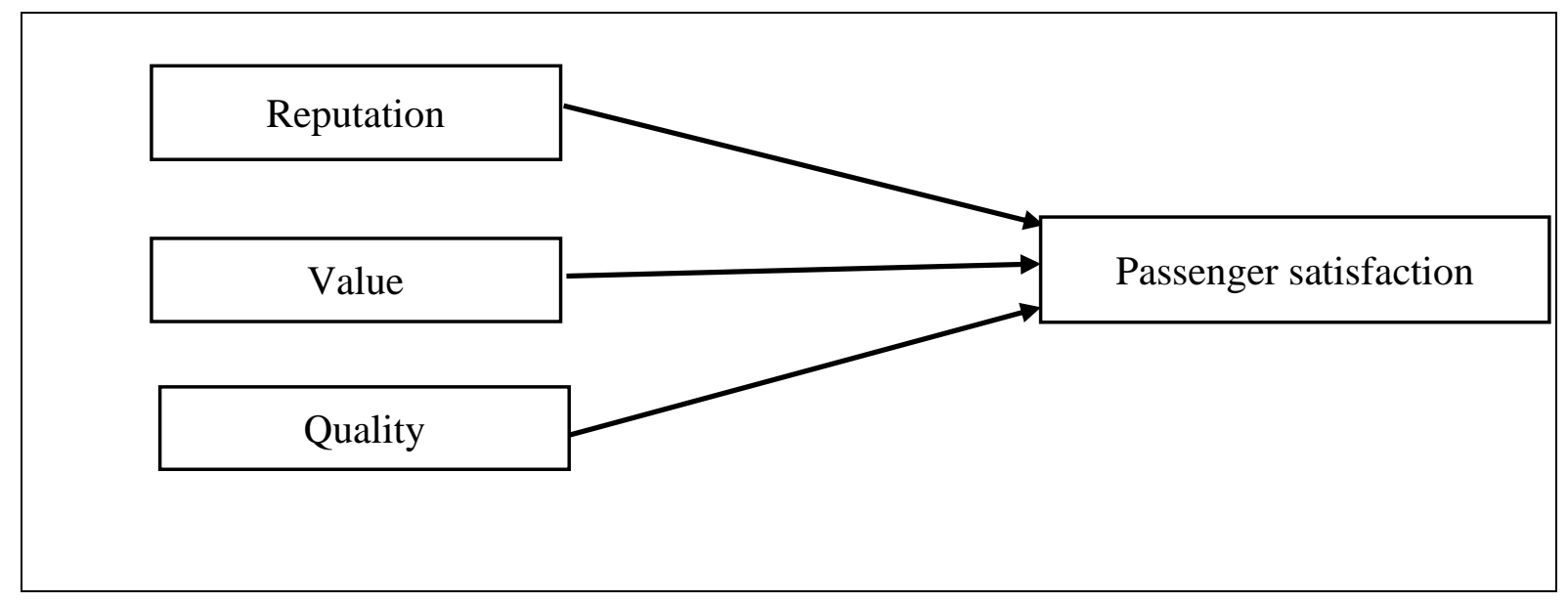

\section{Results}

The location of the survey was done at the LRT Taman Jaya due to the reason that it was a strategic location for free shuttle bus users. It was the first and last stop for two buss routes, PJ01 and PJ02. The buses will be parked there for their rest time and when not in service. A total of 322 respondents were picked to answer the survey questions which included school students, universities students, employees and senior citizens; both local and foreigners. The main purposes of this survey is to know the customer satisfaction, quality and reputations of the shuttle buses. The surveys were done for the several days. Most of the respondents will gather at $4 \mathrm{pm}$ every day at the LRT Taman Jaya. Some of them gave the recommendation about the PJ City Bus and talked positively about the shuttle busses. This results are analysed based on variable used in the questionnaire which are satisfactions, value, quality and reputation. 


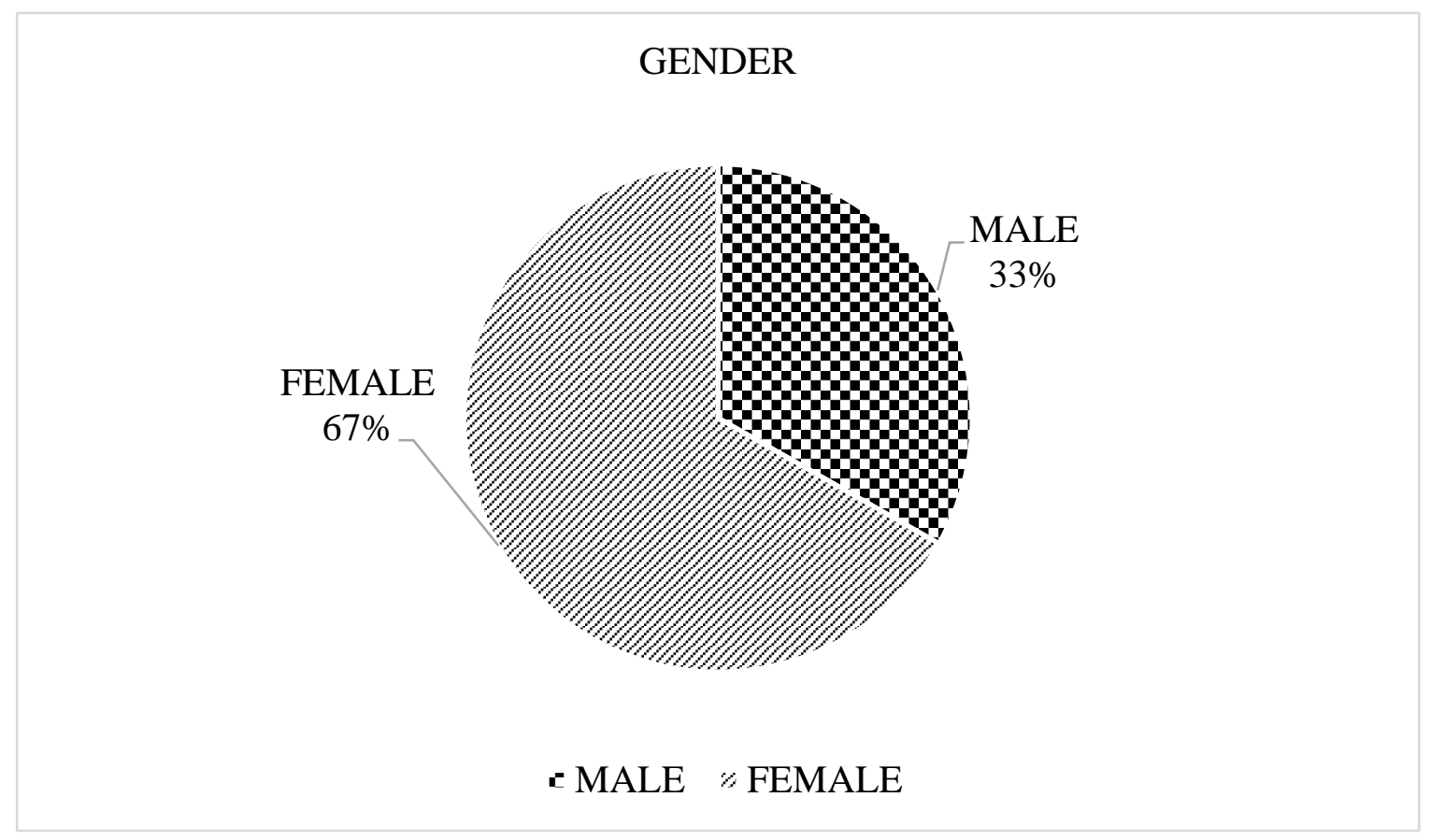

Figure 3: Age

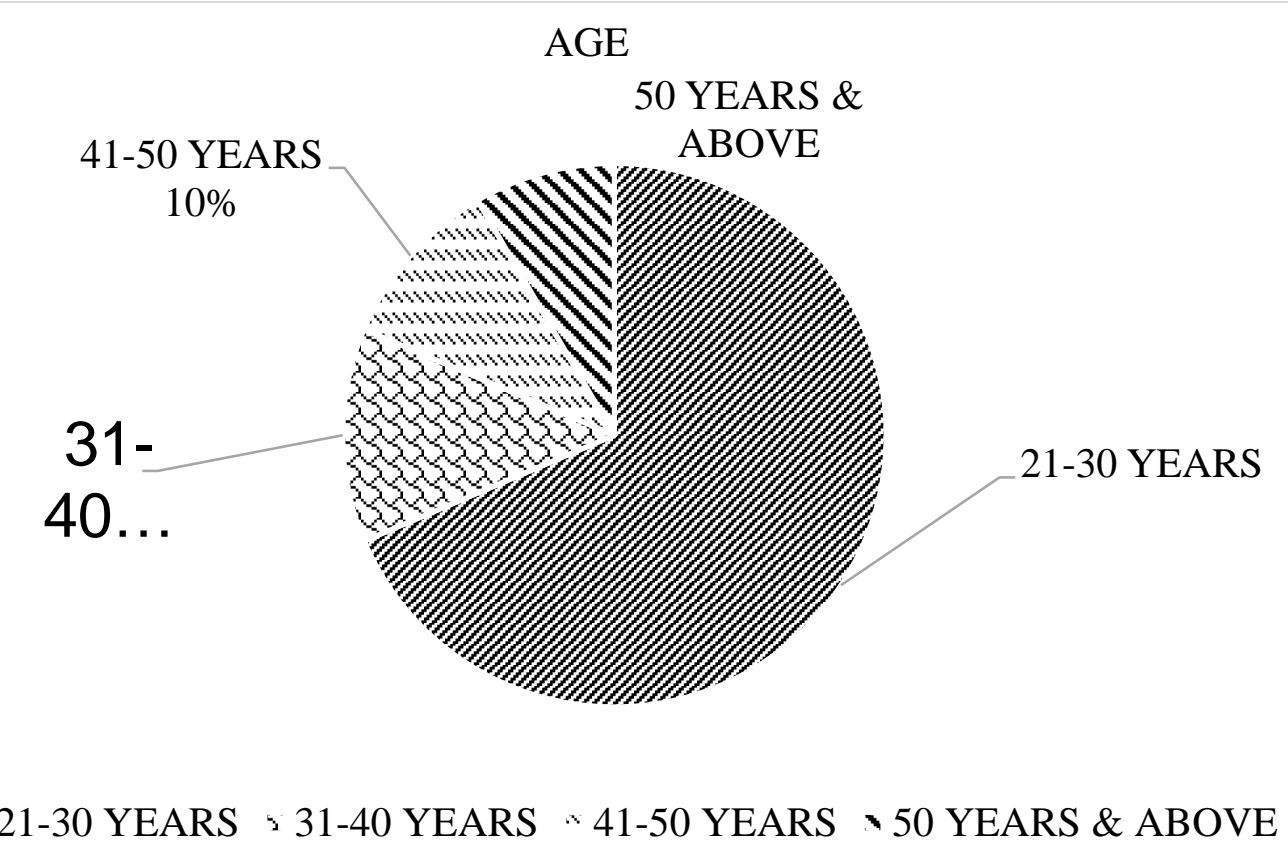


Figure 4: Level of education

\section{LEVEL of EDUCATION}

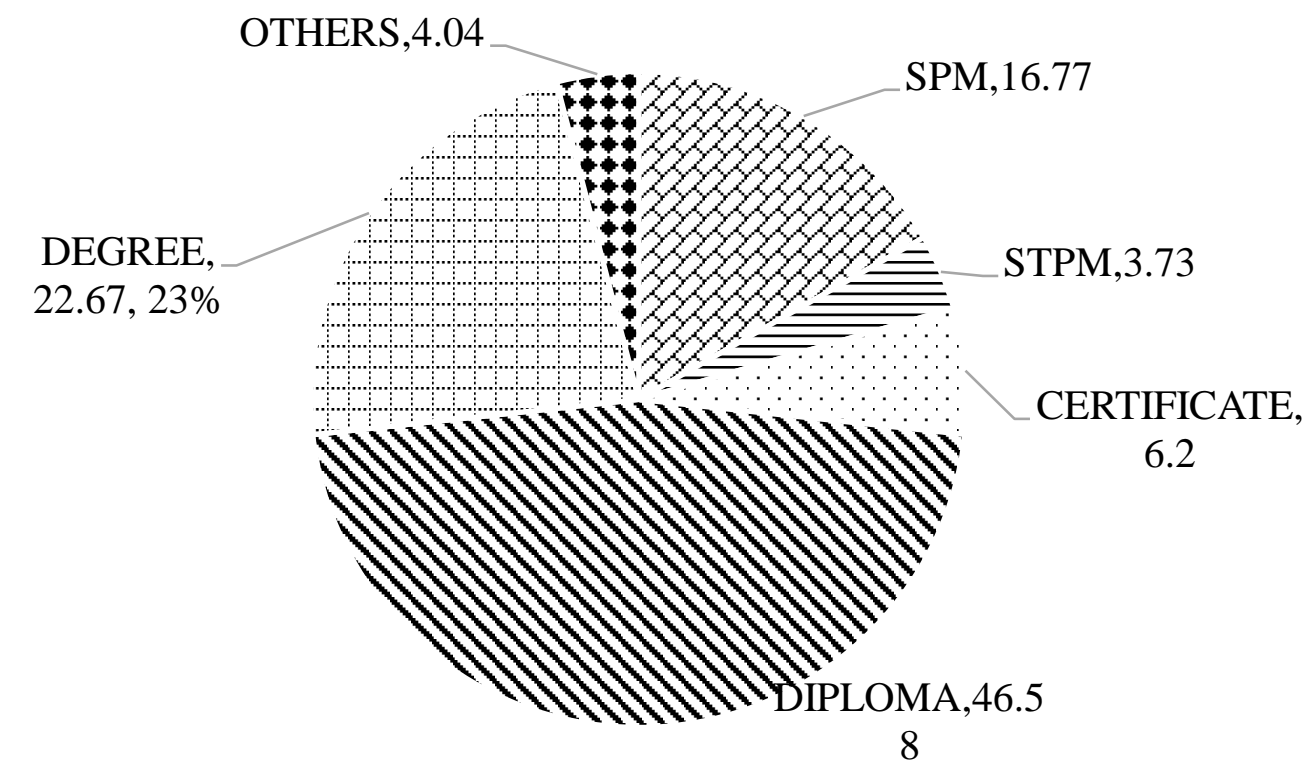

$\triangle \mathrm{SPM}=\mathrm{STPM} \cdot \mathrm{CERTIFICATE} \cdot \mathrm{DIPLOMA}$ DEGREE $*$ OTHERS

Figure 5: Income

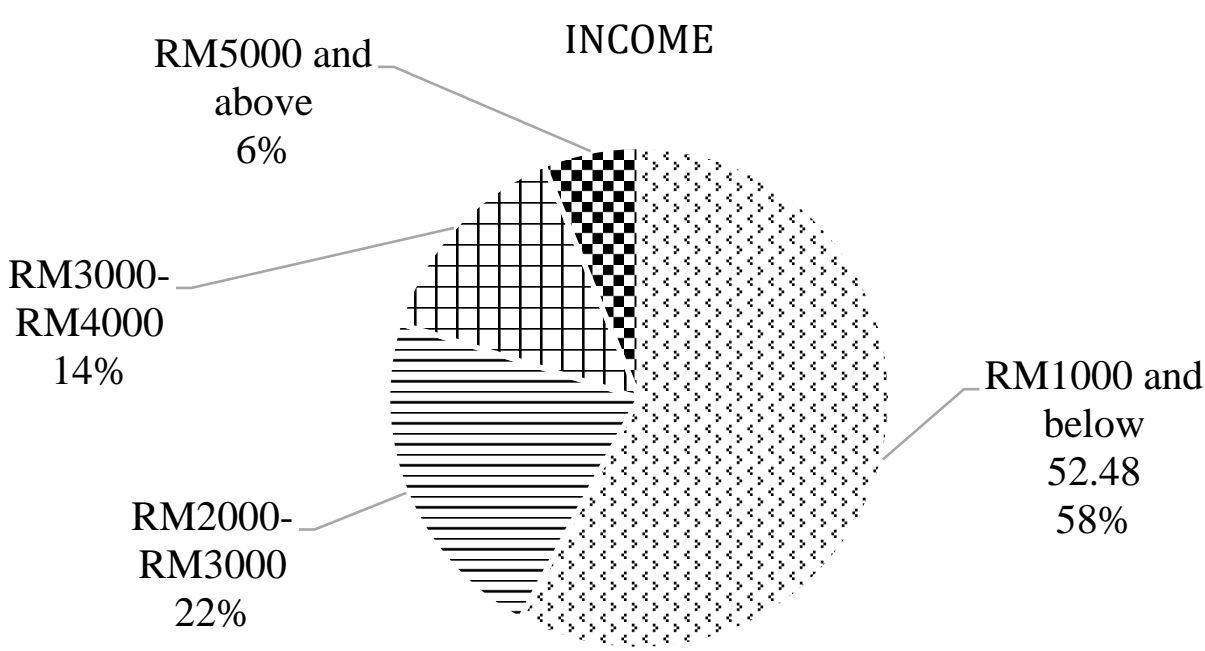

$\therefore$ RM1000 and below $=$ RM2000-RM3000

+ RM3000-RM4000 י RM5000 and above 
Malaysian Journal of Social Sciences and Humanities (MJSSH), Volume 6, Issue 11, (page 427 - 441), 2021

DOI: https://doi.org/10.47405/mjssh.v6i11.1149

Figure 6: Marital status

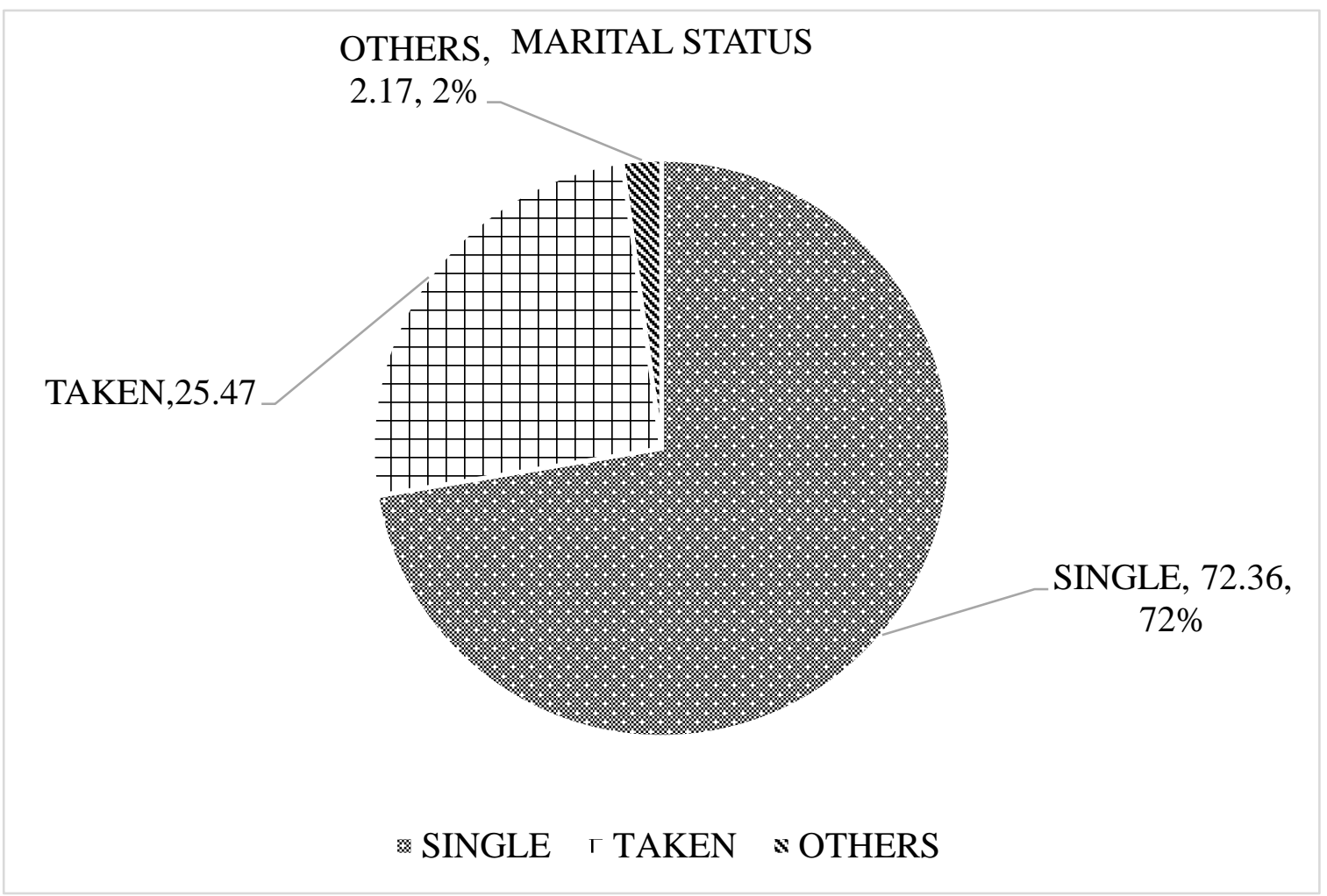

Figure 7: Work experience

\section{WORK EXPERIENCE}

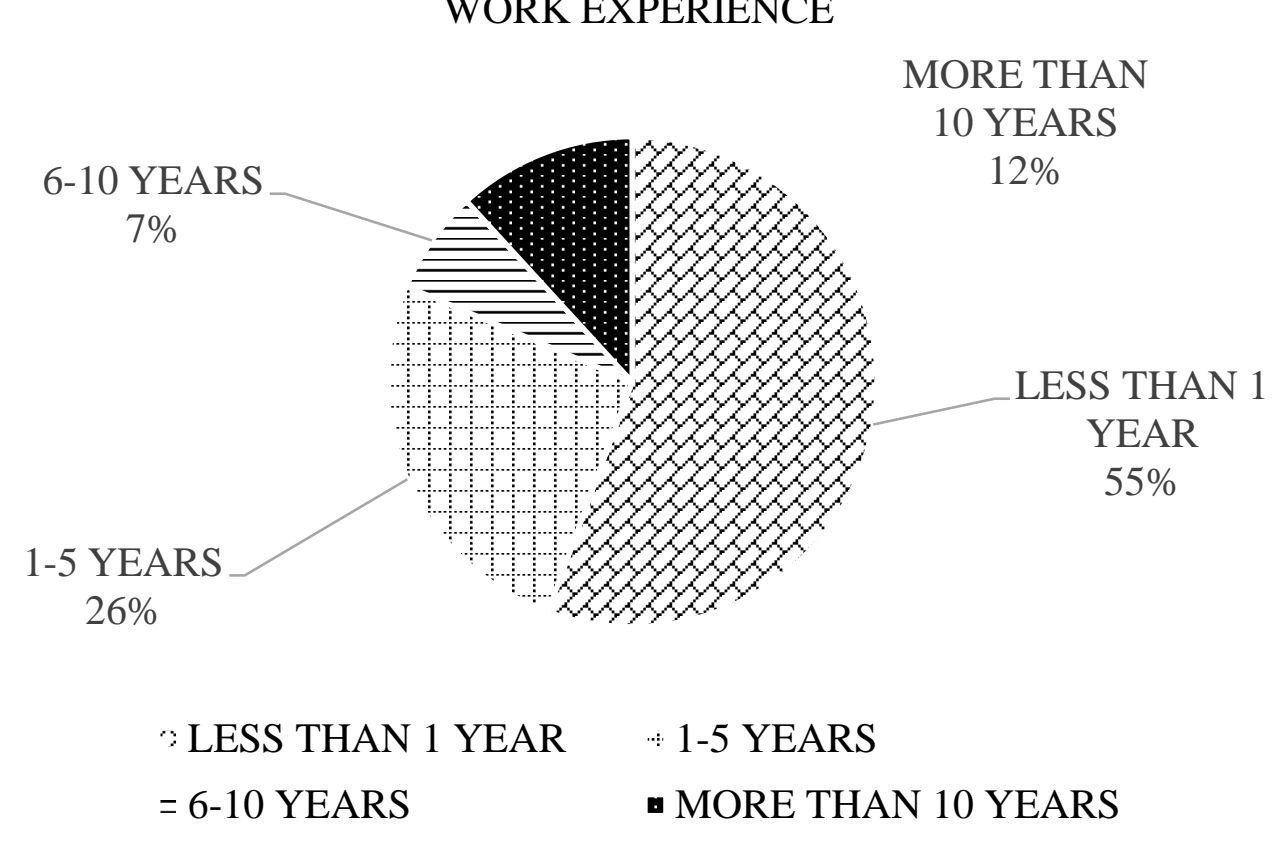


Figure 8: Working hours

\section{WORKING HOURS}

NORMAL , 59.93

\section{"SHIFT ^NORMAL}

Figure 9: Satisfaction

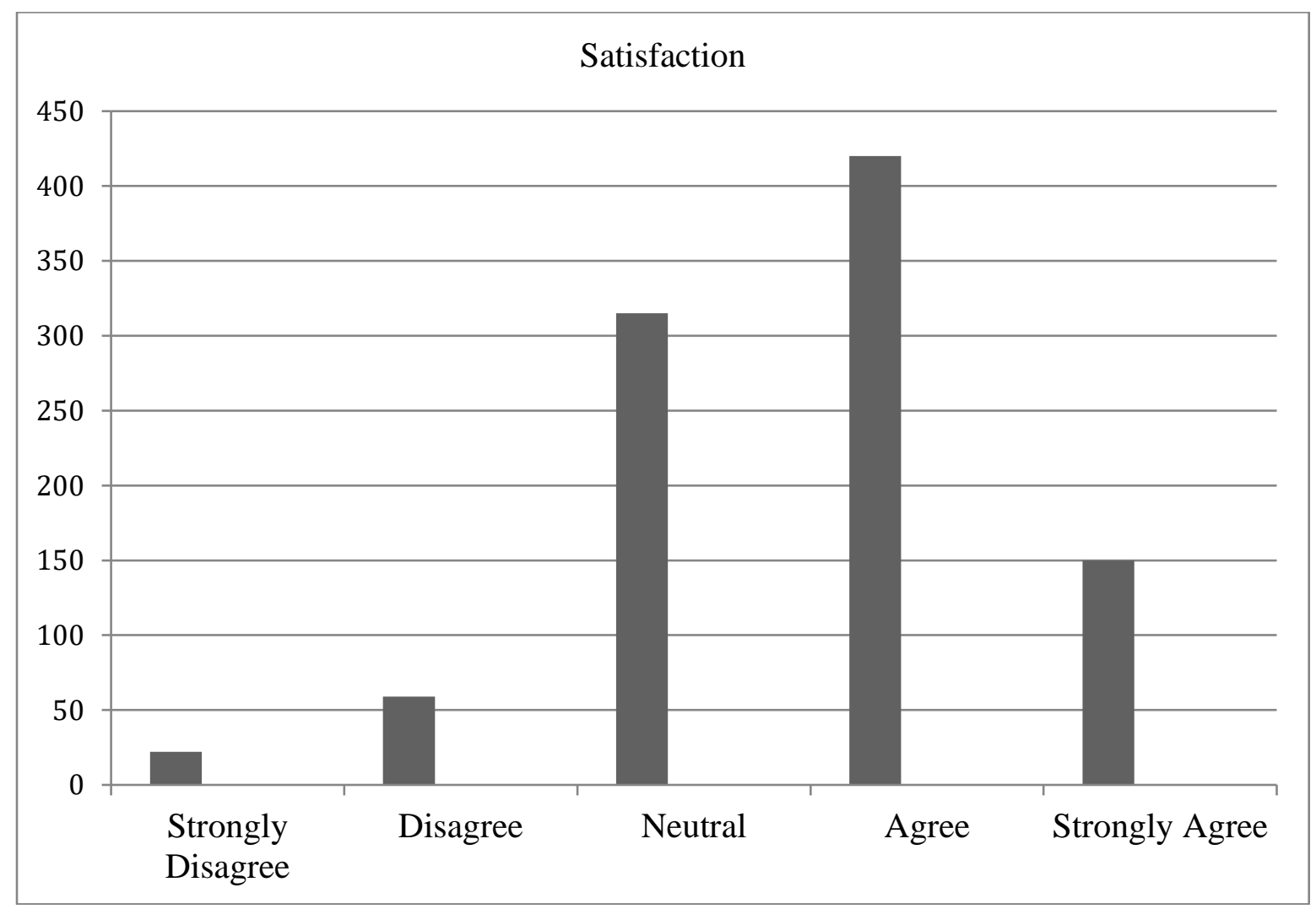


Figure 10: Value

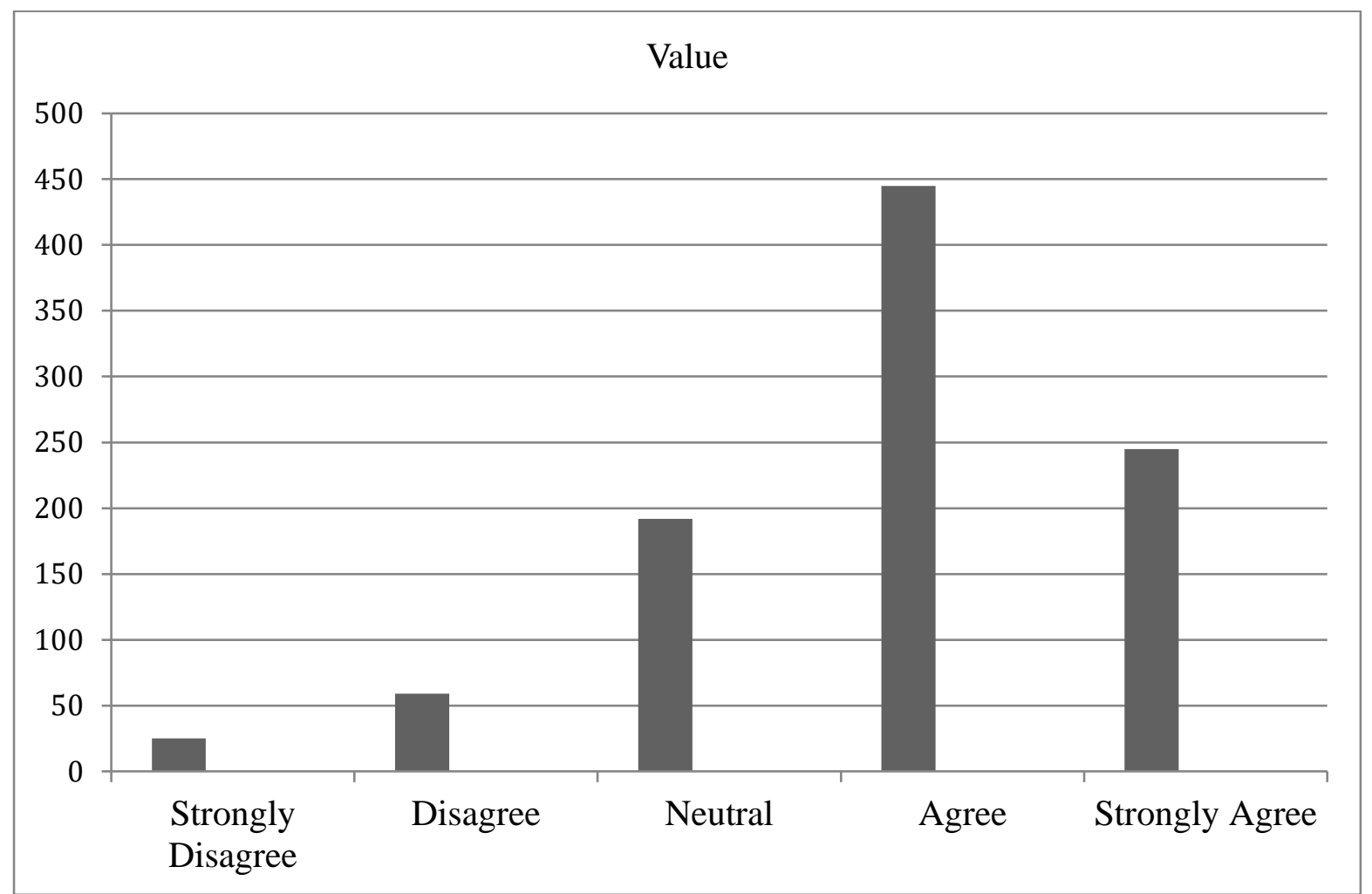

Figure 11: Quality

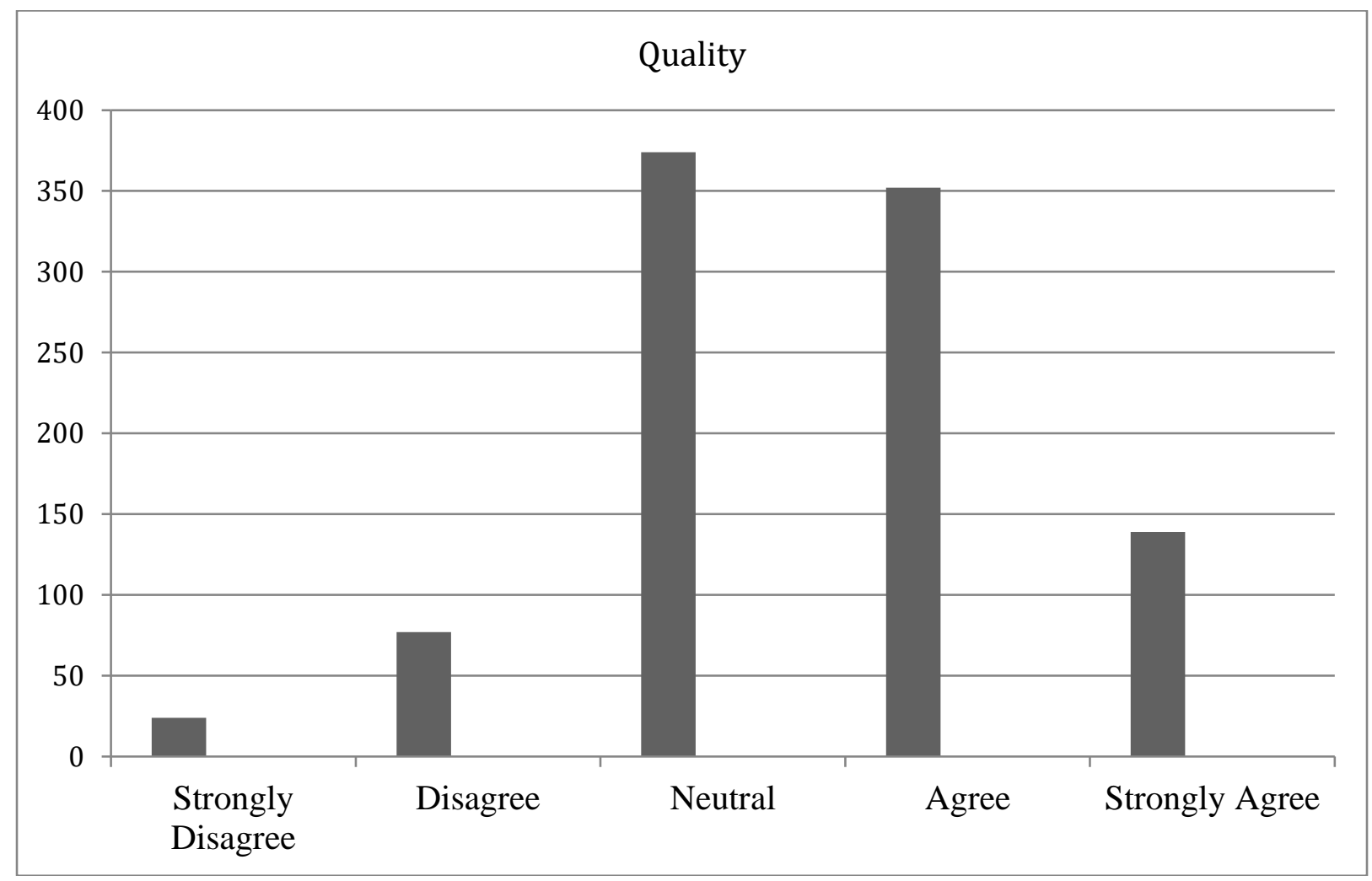


Figure 12: Reputation

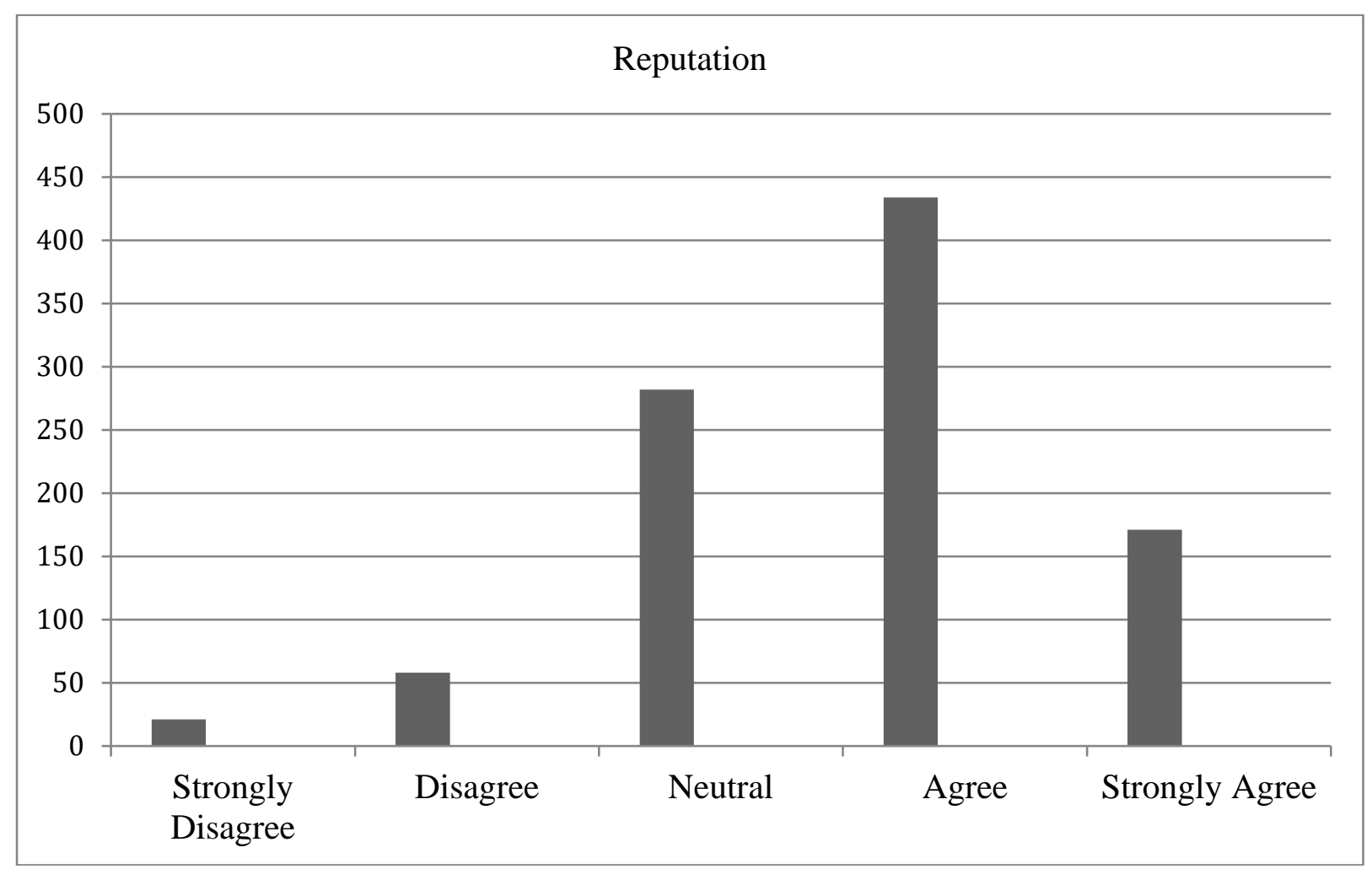

\section{Discussion}

Based on the data collect it can seen that most of the respondent are female (215 respondent). Meanwhile, the number of of men respondents involved in complete the survey is 107 respondents. This indicates that more women use the bus to travel. The age in this survey is divided into four groups. Out of the total number, 221 respondents are in the 21 years to 30 years old group. This shows the highest number, as the youths nowadays prefer to take the public transport as they can save their expenditure in travelling. In this survey, the level of education is divided onto six separate groups. The highest number of respondents are in the diploma in education programme (150 respondents). There are 7 Masters , 4 PhDs, 1 SRF and 1 PG students. 169 respondents earn an income of RM1000 and below. Another 64 respondents earn an income of RM1000 to RM2000. From their incomes it can be concluded that most of them who are in the lower income group prefer to use public transport as it helps to reduce their travelling expenditure. The data collected shows 233 respondents are single and 82 respondents are married. Besides, 179 respondents have less than 1 year working experience. . These new workers usually take an easy and shorter road to their work. Lastly193 respondents follow normal working hours and 129 respondents follow shift working hours.

The bar chart Figures 4.8, 4.9 and 4.10 above show the results for the three questions for each part which is satisfaction, value, quality and reputation. From the bar chart for satisfaction, the it shows that 22 strongly disagree , 59 disagree ,315 are neutral , 420 agree and 150 strongly agree. The number of respondents who agree is the highest which means that most users of the free shuttle bus are satisfied with the services provided by the PJ City Bus because it has fulfilled the respondent's expectations and needs. However, those who strongly agree to show their satisfaction is the lowest which means there are many users who are not satisfied with services of PJ City Bus.

The second bar chart,Figure 4.9 is for value There are 25 who strongly disagree , 59 disagree, 192 are neutral 192, 446 agree and 245 strongly for value. Most of respondents agree that PJ City Bus provides convenient transportation for them and the bus has given a service that allows the respondents to go to different parts of the city in the easiest way. 
Next, the bar chart illustrates the result of the quality of the bus service. From the total number 24 strongly disagree ,77 disagree , 374 are neutral , 352 agree and 137 strongly agree. The result of neutral number for quality is the highest which shows that the respondents are not really satisfied with the quality of services that is provided by PJ City Bus but overall the quality is good.

Lastly, the bar chart on the reputation of PJ City Bus reveals that 21 strongly disagree is 21, 58 disagree ,282 are neutral ,434 agree and 171strongly agree regarding its reputation. The highest result shows that the users of PJ free shuttle bus have agreed that the bus has a good reputation and the image of PJ City Bus is positive. The respondents also agreed that PJ City Bus is a good from of transport for them to move because it's near to the LRT station.

In this research data was collected from 322 respondents. The purpose of this pilot test was to ensure the customers satisfaction. Besides that, the data was analysed and reported using descriptive analysis for gender, age, level of education income, marital status, working hours and working experience. The purpose of the reliability test was to know whether the independents variables and dependent variables have a relationships to each other. Moreover, by applying the final outcome of every test in this research, it is highly possibly to measure between the customer satisfaction with value and reputation of PJ City bus service. Lastly, this finding also can give a few recommendations for future research. The study was carried out concerning the main objective of assessing the factors associate with customer satisfaction on the free shuttle bus at Petaling Jaya.

The study revealed that value is the main factor that contributes to the customer satisfaction of the PJ City Bus. Most of the respondent's agreed that the value provided by PJ City Bus is an attraction for them to continue using the PJ City Bus. The main reason as to why value is the highest is because PJ City Bus provides a free fare bus service that allows them to access the Petaling Jaya City. By using the free bus service, the respondents could save their money on the transportation. Besides, it can also help in reducing traffic jam in Petaling Jaya.

\section{Implication of the Study}

Contrary to initial expectations, customer satisfaction of PJ City Bus was not influenced by quality and reputation of the free shuttle bus. There are a few implications that have been figured out. The implication is derived from the factors that are associated with customer satisfaction of the PJ City Bus. First, is safety as a priority of the bus services. As far as concern, the outcome shown that user of PJ City Bus always think about their safety first. Quality alone cannot influence the satisfaction of customers of the PJ City Bus as safety is a part of the value of the quality of service. In addition, (Imam, 2015) says that quality of services can maintain existing users and attract new passengers. Contrary to this research, previous research on Rapid Penang (Hilmi,Ayub \& Haji Hamzah, 2015) showed that users focused on value more than quality because user has been used to the quality level that they no longer relate it to satisfaction. Finally, the management needs to improve their value rather than the reputation of the company. The findings of study show that users were not concerned about the reputation of PJ City Bus that might influence their satisfaction. This is similar to the past studies of Rapid Penang (Hilmi,Ayub \& Haji Hamzah, 2015). Both the research found out that users just want to go to their destination using the lowest cost possible. They never linked a good reputation, positive image and smart way to travel as part of customer satisfaction. Besides, the study of Rapid Penang also had suggested to improve the value as strategies to improve customer satisfaction. Due to that, management needs to take it as an opportunity to give better services to the users. From this research, we know the quality, value and reputation are very powerful factors for measuring the customer satisfaction. Thus, the main interest of this study is to find out the customer satisfaction with the quality of services provides by the public transport and changing their perception on zero- fare as quality does not depend on the charges. In conclusion, this study is beneficial for the free shuttle bus in Petaling Jaya in helping them to achieve a favourable position in the future and also be beneficial to the users and society. 


\section{Conclusion}

The research had taken eight weeks to be completed, from the brainstorming process until the completion of the report. The graph had clearly shown most respondents satisfied with the free bus services. Quality is rated at neutral and need more improvement while value and reputation gain agreeable results. It can be concluded that the services given has made many citizen happy but still need changes. On 5.4, limitations on studies had been stated and suggestions on how to improve them will be discussed here as to help further studies to achieve better results. Firstly, future researcher must put full commitment when doing survey and favourably to have persuasion skills in order to deal with uncooperative potential respondents. A small reminder for all, everyone must be brave and did not shy away from approaching people to answer the survey so that the survey can be finished earlier. Next, the survey questions preferably to be in simple and easy to understand form. As this survey is targeting on public audience regardless their education backgrounds, it is better to use simpler terms so everyone can comprehend them easily. Lastly, this research did not focus on the nationality of the respondents. Further researchers should put nationality in the survey so their perception of Malaysian public services can be obtained.

\section{References}

Ababneh, M. M. (2017). Service quality in the hospitality industry. Journal of Tourism \& Hospitality, 06(01). doi:10.4172/2167-0269.1000e13

Elma, Z. A. M. (2015). The study on customer satisfaction of public transport in Melaka by using service quality dimensions: A case study of panorama Melaka.

Factors influencing public transport passengers' satisfaction: A New model. Management of Environmental Quality: An International Journal, 27(5), 585-597. doi:10.1108/meq-05-20150084

Gray. R. B. (2017). What is zero-based budgeting, and how can it help small businesses? Retrieved August 1, 2021, from https://www.patriotsoftware.com/

Harifah, M. N., Na'asah, N., \& Foo, J. (2019). Determinants of customer satisfaction of service quality: City Bus services in Kota Kinabalu, Malaysia. Kota Kinabalu, Malaysia.

Hilmi, M. F., Ayub, M. A., \& Haji Hamzah, H. (2015). User Satisfaction of Public Transport: An Exploratory Study in Penang, Malaysia. Journal of Business Innovation and Research, 2(4), 114.

Imam, R. (2014). Measuring public transport satisfaction from user surveys. International Journal of Business and Management, 9(6). doi:10.5539/ijbm.v9n6p106

Kotler, P., Kartajaya, H., \& Setiawan, I. (2017). Marketing 4.0 moving from traditional to digital. Hoboken, NJ: John Wiley \& Sons

Liu, Y., Siall, F., Darun, M.R., \& Ismail, M.F. (2014) Service quality and customer: Rapid Kuantan in Kuantan route, Malaysia. International Conference on Social Sciences and Humanities, 8(10).

Marbach, J., Lages, C. R., \& Nunan, D. (2016). Who are you and what do you value? Investigating the role of personality traits and customer-perceived value in online customer engagement. Journal of Marketing Management, 32(5-6), 502-525.doi:10.1080/0267257x.2015.1128472

Mohamed Irtema, H.I., Ismail, A., Borhan, M.N., Abdelsalam, H.M., Alshetwi, A.B.Z., Albrka, S.I., Milad, A., Mohashhash, B., Alfakhri, A.Y.Y., Muhammad Das, A., Yahia, H.A.M., \& Al Allam, A.M. (2018). Perceptions passenger on service quality:Public Transport in Kuala Lumpur. Retrieved September 20, 2021, from https://www.researchgate.net/

Njei, Z. (2018). Relationship between customer satisfaction and customer loyalty. Retrieved August 20, 2021, from https://www.theseus.fi/bitstream/handle/10024/146823/

Parahoo, S. K., Harvey, H. L., \& Radi, G. Y. A. (2014). Satisfaction of tourists with public transport: An Empirical investigation in Dubai. Journal of Travel \& Tourism Marketing, 31(8), 10041017.

Qomariah, N. (2017). Impact of customer value, brand image and product attributes to satisfaction and loyalty tourism visitors in Jember Regency. Mediterranean Journal of Social Sciences, 8(5-1), $129-135$. 
DOI: https://doi.org/10.47405/mjssh.v6i11.1149

Rabiul, I., Mohammed, S. C., Mohammad, S. S., \& Salauddin, A. (2014). Measuring customer's satisfaction on bus transportation. Retrieved September 2, 2019, from https://thescipub.com/

Santuri, P. T., \& Baharom, N. A. (2018). The public perception of public transportation in Malaysia. Retrieved, September, 2021, from https://www.academia.edu/37990833/

Sokchan Ok, (2018). Customer satisfaction on service quality of bus transport: A Survey of passenger from Phnom Penh to Poipet in Cambodia. Journal of Social Science Studies, 5(2), 114-131.

Sumaedi, S., Bakti, I. G., Rakhmawati, T., Astrini, N. J., Widianti, T., \& Yarmen, M. (2016).

Zakiah, P., Syahirah, B., Mansor. I., \& Mariana, M. (2016). Assessing passengers' satisfaction level on bus services in selected urban and rural centres of peninsular Malaysia. Procedia - Social and Behavioral Sciences 222 (2016) 837-844.

\section{Authors' Details}

1. Nur Adibah Farhanah Binti Ismail, Nur Alya Imani Binti Ismail, Nur Intan Faaiqah Binti Mohd Faizal, Nur Rabiatul Adawiyah Atiqah Binti Ijaman, Nuramira Adiyana Binti Suzeli, Nurul Ainina Binti Amir Ezam, Tan Sheau Wei. These authors were Diploma final year students from University of Malaya Centre for Continuing Education (UMCCeD). This was a group work for Business Research Methodology UDE 2012 which was supervised by Mr. Isai Amutan Krishnan. Ms. Vimala Davy G. Ramiah and Ms. Sio Ching Hee were also contributed significantly for completing this final year project.

2. Vimala Davy G. Ramiah is currently the head of the Department of Staff Development at Institute Aminuddin Baki, Sarawak Branch in Kuching, Sarawak. She was prior to this the Head of the Unit at the Schools and Sports Divisions of the Ministry of Education in Putrajaya. She has more than 32 years of working experience in the field of education with the Ministry of Education, Malaysia. Her research interests are in communication, applied linguistics and Teaching English as a Second Language.

Email:vimala@iab.edu.my, HP: 0192194642

Address: Institut Aminuddin Baki Sarawak Branch, Jalan Sultan Tengah, 93050 Kuching, Sarawak.

3. Sio Ching Hee: Lecturer/Trainer, ELM Business School, HELP University, Jalan Sri Semantan 1, Off Jalan Semantan, Bukit Damansara, 50490 Kuala Lumpur, Malaysia.

4. Isai Amutan Krishnan: Senior Lecturer, School of Liberal Arts, Science and Technology, PERDANA University,Suite 5.3 5th Floor Wisma Chase Perdana Jalan Semantan Damansara Heights, Wilayah Perseketuan, Malaysia. 